\title{
PENGARUH PENYULUHAN TENTANG BKB (BINA KELUARGA BALITA) TERHADAP PENGETAHUAN DAN KEAKTIFAN IBU DALAM KEGIATAN BKB
}

\author{
Mitayakuna Stianto ${ }^{1}$ \\ ${ }^{1}$ Stikes Bahrul Ulum Jombang \\ Email : mitayaku@gmail.com
}

\section{ABSTRACT INFLUENCE INFORMATION ABOUT BKB (CHILD FAMILY DEVELOPMENT) OF KNOWLEDGE AND LIVELINESS MOTHER IN ACTIVITIES BKB}

Backgroumnd The BKB important to enhance resistance family esp in the role of optimize growth and development for children under five. A lack of understanding of the toddler mother BKB can cause the toddler did not attend $B K B$.

The purpose of research is analyzing the information about BKB effects on knowledge about and liveliness mother in activities in the village in BKB Keras Diwek Jombang district.

Methods Design used the model one group post pra-test test design. Population is all mother bulan-36 have children age 3 months. Sampling technique using a technique simple random sampling with large samples from 60 respondents. Independen variable is knowledge and liveliness mother in BKB activities before it was given information about BKB and variable dependen knowledge and liveliness mother in BKB activities after given information about BKB. An instrument use questionnaire sheets. Statistical tests use the wilcoxon on the mistake level (a) 0,05.

The results of the study before given information obtained almost all respondents prescience enough 49 as many as percent of respondents $(81,7)$ and the majority of respondents active BKB 33 activities as many as percent of respondents (55), after counseling and have found the majority of respondents prescience enough 44 as many as percent of respondents $(73,3)$ and the majority of respondents in the active BKB 33 as many as percent of respondents (55). The analysis result of knowledge or value $p$-value 0,005 and liveliness value $p$-value 0,000

Conclusion the value of p-value 0,005 and 0,000 $<0.05$, so h0 were rejected and $h 1$ received which would mean there are the information about BKB effects on knowledge about and liveliness mother in activities in the village in BKB Keras Diwek Jombang district.

Suggestion Enough mother and knowledge about BKB made mother and capable of change behavior to actively in the BKB.

Keywords: information, BKB, knowledge, liveliness

\section{ABSTRAK}

Latar Belakang Program BKB penting untuk meningkatkan ketahanan keluarga khususnya dalam peran mengoptimalkan pertumbuhan dan perkembangan anak balita. Kurangnya pemahaman ibu balita tentang BKB dapat menyebabkan ibu balita tidak mengikuti BKB.

Tujuan penelitiannya adalah menganalisis pengaruh penyuluhan tentang BKB terhadap pengetahuan dan keaktifan ibu dalam kegiatan BKB di Desa Keras Kecamatan Diwek Kabupaten Jombang.

Metode Desain penelitian menggunakan model one group pra-test post test desain. Populasinya adalah semua ibu yang memiliki anak usia 3 bulan-36 bulan. Teknik sampling menggunakan teknik simple random sampling dengan besar sampel sebanyak 60 responden. Variabel independennya adalah pengetahuan dan keaktifan ibu dalam kegiatan BKB sebelum diberikan penyuluhan tentang BKB dan variabel dependennya pengetahuan dan keaktifan ibu dalam kegiatan BKB sesudah diberikan penyuluhan tentang BKB. Instrumen menggunakan lembar kuesioner. Uji statistik menggunakan uji wilcoxon dengan tingkat kesalahan (a) 0,05.

Hasil penelitian sebelum diberi penyuluhan didapatkan hampir seluruh responden pengetahuannya cukup sebanyak 49 responden $(81,7 \%)$ dan sebagian besar responden aktif kegiatan BKB sebanyak 33 responden $(55 \%)$, sedangkan sesudah diberi penyuluhan didapatkan sebagian besar responden pengetahuannya cukup sebanyak 44 responden $(73,3 \%)$ dan sebagian besar responden aktif dalam kegiatan BKB sebanyak 33 responden (55\%). Hasil analisa pengetahuan didapatkan nilai $p$-value 0,005 dan keaktifan nilai $p$-value 0,000 , karena nilai $p$-value 0,005 dan $0,000<0,05$, maka $\mathrm{H} 0$ ditolak dan $\mathrm{H} 1$ diterima. 


\section{JKM (Jurnal Kebidanan Malahayati),Vol 7,No.3.Juli 2021, ISSN (Print) 2476-8944 ISSN (Online) 2579-762X, Hal 562-567}

Kesimpulan ada pengaruh penyuluhan tentang BKB terhadap pengetahuan dan keaktifan ibu dalam kegiatan BKB di Desa Keras Kecamatan Diwek Kabupaten Jombang.

Saran Pengetahuan cukup ibu balita tentang BKB menjadikan ibu balita mampu merubah perilaku untuk aktif dalam kegiatan BKB.

Kata kunci: penyuluhan, BKB, pengetahuan, keaktifan

\section{PENDAHULUAN}

Program Bina Keluarga Balita (BKB) penting untuk meningkatkan ketahanan keluarga khususnya dalam peran mengoptimalkan pertumbuhan dan perkembangan anak balita (BKKBN, 2018). Namun pada kenyataannya, pelaksana program BKB atau petugas tidak memahami dengan BKB sehingga petugas belum menyadari, menangkap, dan tidak melihat besarnya kebutuhan pelatihan, besarnya sarana prasarana, dan konsekuensinya terhadap pelaksanaan program. Hal ini menyebabkan BKB mengalami penurunan kinerja dan belum berjalan optimal, sehingga tujuan BKB tidak sampai kepada keluarga balita dan masih banyak keluarga yang tidak memahami tentang BKB (BKKBN, 2013). Kurangnya pemahaman ibu balita tentang $B K B$ ini menyebabkan ibu balita tidak mengikuti BKB (Depkes Rl, 2018).

Jumlah kelompok BKB secara Nasional yang melapor kepada BKKBN pada tahun 2018 sebanyak 73.257 (92,63\%) dari 79.082 kelompok yang ada. Jumlah keluarga yang hadir dalam kegiatan BKB sebanyak 2.978 .756 (82,7\%) dari 3.598.775 keluarga yang tercatat sebagai anggota BKB (BKKBN, 2018). Sedangkan jumlah kelompok BKB di Propinsi Jawa Timur sebanyak 11.238 BKB, Kabupaten Jombang sebanyak 1348 BKB dan UPTD Puskesmas Brambang sebanyak 10 BKB. Hasil penelitian Wahyuni dkk (2019) di Kabupaten Jember menunjukkan bahwa $73,8 \%$ ibu yang tidak mengikuti kegiatan BKB mempunyai pengetahuan yang rendah dan $100 \%$ ibu yang mengikuti kegiatan BKB mempunyai pengetahuan yang tinggi. Hal ini menunjukkan bahwa ibu yang berpengetahuan tinggi cenderung mengikuti kegiatan BKB dan yang berpengetahuan rendah tidak mengikuti BKB. Berdasarkan studi pendahuluan pada tanggal 22 April 2019 di Desa Keras Kecamatan Jombang Kabupaten Jombang dengan cara wawancara pada sebanyak 5 ibu balita yang ditemui di Desa Keras, didapatkan sebanyak 4 orang (80\%) mengatakan tidak mengetahui tentang kegiatan BKB, mereka hanya tahu kegiatan posyandu sehingga tidak pernah mengikuti kegiatan BKB, sedangkan 1 orang $(20 \%)$ mengatakan bahwa mereka mengetahui tentang BKB dan ibu juga mengikuti kegiatan tersebut 2 kali dalam satu bulan.
Dampak yang muncul dari ibu balita yang tidak aktif mengikuti kegiatan BKB, maka ibu tidak akan mendapatkan informasi tentang pentingnya ASI, MP ASI, gizi seimbang, prinsip pengasuhan yang benar, pemantauan pertumbuhan dan perkembangan anak, stimulasi tumbuh kembang balita untuk peningkatan kualitas anak dan keluarga balita tidak akan mendapatkan bantuan untuk melakukan rujukan apabila ada keterlambatan perkembangan pada anak sehingga mengakibatkan pertumbuhan dan perkembangan anak terganggu (Waluyo, 2019).

Upaya yang dapat dilakukan Bidan yaitu dengan memberikan KIE pada ibu balita tentang pentingnya $B K B$, membagikan leaflet tentang $B K B$ dan mengajarkan ibu balita tentang penggunaan KKA (Kartu Kembang Anak) guna memantau perkembangan anak, sehingga ibu balita mengetahui perkembangan anak dan pentingnya stimulasi perkembangan anak yang banyak didapatkan melalui kegiatan BKB (BKKBN, 2015). Untuk meningkatkan kuantitas dan kualitas program BKB, maka perlu dilakukan berbagai kegiatan inovatif seperti keterpaduan pelaksanaan program, menyelenggarakan pelatihan dan orientasi bagi kader, membuat laporan pelaksanaan pelatihan dan orientasi, melakukan evaluasi hasil pelaksanaan pelatihan dan orientasi (Burhanuddin, 2019).

Berdasarkan latar belakang ini, peneliti tertarik untuk melakukan penelitian tentang pengaruh penyuluhan tentang BKB (Bina Keluarga Balita) terhadap pengetahuan dan keaktifan ibu dalam kegiatan BKB di Desa Keras Kecamatan Diwek Kabupaten Jombang.

\section{METODOLOGI PENELITIAN}

Desain penelitian yang digunakan one group pra - test post test desain. Populasi adalah semua ibu yang memiliki anak usia 3 bulan-36 bulan di Desa Keras Kecamatan Diwek Kabupaten Jombang sebanyak 70 anak. Teknik sampling yang digunakan adalah simple random sampling. Sampelnya sebagian ibu yang memiliki anak usia 3 bulan-36 bulan di Desa Keras Kecamatan Diwek Kabupaten Jombang sebanyak 60 responden. Lokasi penelitian adalah Desa Keras Kecamatan Diwek Kabupaten Jombang yang dilaksanakan 
tanggal 9 sampai 23 Maret 2020. Pengolahan data dilakukan dengan editing, coding, skoring dan tabulating. Teknik analisis data dilakukan dengan menggunakan uji statistik Wilcoxon, dengan menggunakan bantuan SPSS.

\section{HASIL DAN PEMBAHASAN}

Tabel 1.

Tabulasi Pengetahuan Tentang BKB Sebelum Diberi Penyuluhan Tentang BKB di Desa Keras Kecamatan Diwek Kabupaten Jombang Pada Tanggal 9 Sampai 23 Maret 2020

\begin{tabular}{|c|c|c|}
\hline Pengetahuan Tentang BKB & Jumlah & $\%$ \\
\hline Kurang & 3 & 5 \\
\hline Cukup & 49 & 81,7 \\
\hline Baik & 8 & 13,3 \\
\hline Total & 60 & 100 \\
\hline
\end{tabular}

Hasil penelitian pada tabel 1 menunjukkan bahwa pengetahuan tentang BKB sebelum diberi penyuluhan tentang BKB di Desa Keras Kecamatan Diwek Kabupaten Jombang didapatkan hampir seluruh dari responden pengetahuannya cukup sebanyak 49 responden $(81,7 \%)$.

Tabel 2.

Tabulasi Pengetahuan Tentang BKB Sesudah Diberi Penyuluhan Tentang BKB di Desa Keras Kecamatan Diwek Kabupaten Jombang Pada Tanggal 9 Sampai 23 Maret 2020

\begin{tabular}{|c|c|c|}
\hline Pengetahuan Tentang BKB & Jumlah & $\%$ \\
\hline Kurang & 0 & 0 \\
\hline Cukup & 47 & 78,3 \\
\hline Baik & 13 & 21,7 \\
\hline Total & 60 & 100 \\
\hline
\end{tabular}

Hasil penelitian pada tabel 2 menunjukkan bahwa pengetahuan tentang BKB sesudah diberi penyuluhan tentang BKB di Desa Keras Kecamatan Diwek Kabupaten Jombang didapatkan sebagian besar dari responden pengetahuannya cukup sebanyak 47 responden $(78,3 \%)$.
Tabel 3.

Tabulasi Keaktifan Kegiatan BKB Sebelum Diberi

Penyuluhan Tentang BKB di Desa Keras

Kecamatan Diwek Kabupaten Jombang Pada Tanggal 9 Sampai 23 Maret 2020

\begin{tabular}{|c|c|c|}
\hline Keaktifan Kegiatan BKB & Jumlah & $\%$ \\
\hline Pasif & 27 & 45 \\
\hline Aktif & 33 & 55 \\
\hline Total & 60 & 100 \\
\hline
\end{tabular}

Hasil penelitian pada tabel 3 menunjukkan bahwa keaktifan kegiatan BKB sebelum diberi penyuluhan tentang BKB di Desa Keras Kecamatan Diwek Kabupaten Jombang didapatkan sebagian besar dari responden aktif kegiatan BKB sebanyak 33 responden (55\%).

Tabel 4.

Tabulasi Keaktifan Kegiatan BKB Sesudah Diberi

Penyuluhan Tentang BKB di Desa Keras

Kecamatan Diwek Kabupaten Jombang Pada Tanggal 9 Sampai 23 Maret 2020

\begin{tabular}{|c|c|c|}
\hline Keaktifan Kegiatan BKB & Jumlah & $\%$ \\
\hline Pasif & 3 & 5 \\
\hline Aktif & 57 & 95 \\
\hline Total & 60 & 100 \\
\hline
\end{tabular}

Hasil penelitian pada tabel 4 menunjukkan bahwa keaktifan kegiatan BKB sesudah diberi penyuluhan tentang BKB di Desa Keras Kecamatan Diwek Kabupaten Jombang didapatkan hampir seluruh dari responden aktif kegiatan BKB sebanyak 57 responden (95\%).

\section{Hasil Uji Statistik}

Hasil analisa data menggunakan uji Wilxocon didapatkan pengetahuan tentang BKB sebelum dan sesudah diberi penyuluhan tentang BKB nilai $p$-value sebesar 0,005 dan keaktifan kegiatan BKB sebelum dan sesudah diberi penyuluhan tentang BKB nilai $p$-value sebesar 0,000 dengan signifikasi pengaruh menggunakan nilai $p$-value $<a(0,05)$, maka nilai $p$-value 0,005 dan $0,000<0,05$, sehingga $\mathrm{H} 0$ ditolak dan $\mathrm{H} 1$ diterima yang artinya ada pengaruh penyuluhan tentang BKB (Bina Keluarga Balita) terhadap pengetahuan dan keaktifan ibu dalam kegiatan BKB di Desa Keras Kecamatan Diwek Kabupaten Jombang. 
Tabel 5.

Pengaruh Penyuluhan Tentang BKB (Bina Keluarga Balita) Terhadap Pengetahuan Dan Keaktifan Ibu Dalam Kegiatan BKB di Desa Keras Kecamatan Diwek Kabupaten Jombang Pada Tanggal 9 Sampai 23 Maret 2020

\begin{tabular}{l|r|r}
\hline & $\begin{array}{c}\text { Pengetahuan.ssdh.penyuluhan - } \\
\text { Pengetahuan.sblm.penyuluhan }\end{array}$ & $\begin{array}{c}\text { Keaktifan.ssdh.penyuluhan - } \\
\text { Keaktifan.sblm.penyuluhan }\end{array}$ \\
\hline Z & $-2.828^{\mathrm{b}}$ & $-4.899^{\mathrm{b}}$ \\
Asymp. Sig. (2-tailed) & .005 & .000 \\
\hline
\end{tabular}

a. Wilcoxon Signed Ranks Test

b. Based on negative ranks.

\section{PEMBAHASAN}

Pengetahuan ibu tentang BKB (Bina Keluarga Balita) sebelum diberi penyuluhan tentang BKB

Hasil penelitian ini menunjukkan bahwa pengetahuan responden tentang BKB didapatkan hampir seluruh responden pengetahuannya cukup. Pengetahuan cukup responden dari 60 responden ini didukung oleh faktor umur, pendidikan dan pernah mendapat informasi. Pengetahuannya cukup sebanyak 37 responden ini didapatkan dari responden yang berumur 20-35 tahun. Responden berumur 20-35 tahun dianggap sudah cukup dewasa dalam berpikir dan bertindak dibandingkan dengan responden yang berumur $<20$ tahun, karena semakin bertambahnya umur seseorang, maka tingkat pengalaman dan kematangan jiwanya dalam berpikir dan bertindak juga akan semakin meningkat, sehingga dengan kedewasaan responden akan membantu meningkatkan pengetahuan cukup responden tentang BKB.

Menurut peneliti, pekerjaan responden yang tidak bekerja berpengaruh terhadap pengetahuan responden. Seseorang yang tidak bekerja, sosialisasinya dengan orang lain akan kurang dibanding dengan responden yang bekerja, karena dengan bekerja akan lebih banyak berinteraksi dengan orang lain sehingga tukar pikiran dan dapat menambah pengetahuan responden.

Ditinjau dari informasi, informasi sangat bermanfaat untuk menambah wawasan seseorang, dengan pernah tidaknya mendapat informasi akan berpengaruh terhadap pengetahuan responden. Ada 3 responden yang tidak pernah mendapatkan informasi tentang BKB sebelum diberikan penyuluhan tentang BKB, maka wawasan dan pengetahuan responden menjadi cukup tentang BKB.

Keaktifan ibu dalam kegiatan BKB (Bina Keluarga Balita) sebelum diberi penyuluhan tentang BKB

Hasil penelitian ini menunjukkan bahwa aktifnya kegiatan BKB sebelum diberi penyuluhan tentang BKB ini disebabkan karena ibu kurang memahami akan pentingnya BKB, sehingga tidak ada niat dari ibu untuk aktif ikut BKB. Meskipun sudah ada ibu balita yang pernah mendapatkan informasi tentang BKB, tetapi masih ada ibu balita yang menganggap bahwa BKB tidak ada hubungannya dengan pertumbuhan dan perkembangan balita serta banyak manfaatnya bagi anak balita. Hal ini, didukung oleh kondisi BKB yang kurang menarik pada saat ini, sehingga membuat masyarakat enggan untuk datang ikut BKB. Hal inilah yang menyebabkan banyaknya ibu yang belum aktif semua dalam kegiatan BKB.

Menurut peneliti, pendidikan SMA responden yang pasif dalam kegiatan BKB menunjukkan bahwa pendidikan masih kurang berpikir secara logis dalam bertindak daripada responden yang berpendidikan tinggi, sehingga responden yang berpendidikan SMA masih pasif dalam kegiatan BKB.

Menurut peneliti berdasarkan pekerjaan responden sebelum penyuluhan didapatkan hampir setengah dari responden yang tidak bekerja pasif dalam kegiatan BKB. Responden yang tidak bekerja seharusnya mempunyai banyak waktu untuk mengikuti kegiatan BKB tetapi kenyataan nya ada responden yang belum memahami tentang pentingnya BKB dan ada responden yang pada saat $B K B$ sedang bepergian sehingga pada saat ada kegiatan BKB responden tidak dapat hadir.

Ditinjau dari informasi, informasi sangat bermanfaat untuk menambah wawasan seseorang, dengan pernah tidaknya mendapat informasi akan berpengaruh terhadap perilaku seseorang. Banyaknya responden yang tidak pernah mendapatkan informasi tentang BKB sebelum diberikan penyuluhan tentang $\mathrm{BKB}$, menjadikan responden pasif dalam kegiatan BKB.

Pengetahuan ibu tentang BKB (Bina Keluarga Balita) sesudah diberi penyuluhan tentang BKB

Hasil penelitian ini menunjukkan bahwa pengetahuan responden sesudah diberi penyuluhan 
sebagian besar responden pengetahuannya menjadi cukup. Hal ini membuktikan bahwa penyuluhan tentang BKB yang diberikan dapat diterima oleh responden sehingga dapat menambah wawasan responden tentang BKB dan menambah pengetahuan responden menjadi cukup tentang BKB.

Ditinjau dari faktor pendidikan, responden yang berpendidikan SMA mempunyai cara pandang yang lebih baik daripada responden yang berpendidikan rendah dan sebaliknya responden yang berpendidikan tinggi akan lebih mudah menerima dan menyerap informasi tentang BKB dibandingkan responden yang berpendidikan SMA sehingga sesudah diberikan informasi tentang BKB, pengetahuan responden yang sebelumnya didapat ada yang kurang menjadi cukup sedangkan responden yang sebelumnya cukup didapatkan pengetahuannya baik sesudah diberi penyuluhan.

\section{Keaktifan ibu dalam kegiatan BKB (Bina Keluarga Balita) sesudah diberi penyuluhan tentang BKB}

Menurut peneliti, sesudah diberi penyuluhan, keikutsertaan ibu dalam BKB mengalami peningkatan. Hampir seluruh ibu balita aktif dalam kegiatan BKB sesudah diberi penyuluhan, yang mana sebelum diberi penyuluhan keikutsertaan ibu dalam BKB masih banyak ditemukan yang pasif dalam kegiatan BKB. Hal ini membuktikan bahwa sesudah diberi penyuluhan, sudah ada niat ibu balita untuk ikut aktif dalam kegiatan BKB. Informasi yang akurat tentang apa itu BKB, tujuan, manfaat BKB dapat diterima ibu balita, sehingga ibu balita tahu apa yang harus dilakukan untuk memantau pertumbuhan dan perkembangan balita serta menerapkan pola asuh yang benar pada anak melalui BKB. Masih ada beberapa responden yang tidak ikut kegiatan BKB karena ibu merasa anaknya sehat dan normal sehingga merasa mampu mengasuh sendiri anaknya dengan baik, serta adanya anggapan bahwa BKB kurang menarik dan membosankan menjadikan ibu balita tidak tertarik untuk ikut aktif dalam kegiatan BKB. Alasan lainnya, dikarenakan pekerjaan ibu yang waktunya bersamaan dengan BKB sehingga tidak dapat mengikuti BKB sesudah diberikan penyuluhan.

Menurut peneliti, responden dalam penelitian ini sebagian besar berpendidikan SMA, pendidikan SMA tergolong rpendidikan yang tinggi sehingga lebih mudah untuk menyerap dan memahami informasi dengan baik yang diberikan daripada responden yang berpendidikan SMP. Dan tingkat pendidikan juga mempengaruhi pola piker seseorang, semakin tinggi tingkat pendidikan nya semakin banyak juga wawasan dan pengetahuan nya. Sesudah informasi tentang BKB diberikan melalui penyuluhan, ibu balita berusaha untuk melakukan anjuran sesuai dengan informasi yang ibu dapatkan dari penyuluhan sehingga responden ikut aktif dalam kegiatan BKB. Ibu yang aktif ikut kegiatan BKB salah satu tujuan nya ingin memantau pertumbuhan dan perkembangan anak setiap bulan.

Menurut peneliti, setelah diberikan informasi tentang BKB melalui penyuluhan, maka seluruh responden mendapatkan informasi tentang $B K B$ sehingga mampu menambah wawasan dan pengetahuan responden tentang BKB. Sumber informasi merupakan pemegang peranan yang sangat penting dalam keaktifan kegiatan BKB. Informasi tentang BKB yang didapat dari tenaga kesehatan, dianggap valid dan tidak perlu diragukan kebenarannya, menjadikan responden cenderung mau untuk mengikutinya. Responden menjadi aktif dalam kegiatan BKB.

\section{Pengaruh Penyuluhan Tentang BKB (Bina Keluarga Balita) Terhadap Pengetahuan Dan Keaktifan Ibu Dalam Kegiatan BKB}

Sebelum diberi penyuluhan tentang BKB, responden tidak mengetahui atau tidak pernah mendapatkan informasi tentang BKB dan masih banyak ditemukan ibu balita yang pasif dalam kegiatan BKB. Sesudah diberi penyuluhan didapatkan hampir seluruh responden aktif dalam kegiatan BKB. Hal ini menunjukkan bahwa informasi tentang apa itu BKB, tujuan, manfaat BKB dapat diterima responden. Responden dapat membaca tentang BKB melalui leaflet tentang BKB yang diberikan dan bisa dibaca dirumah, sehingga menambah wawasan, pengertian responden akan pentingnya BKB bagi pertumbuhan dan perkembangan anak balitanya. Bertambahnya wawasan ini maka berdampak pada perubahan perilaku responden. Responden menjadi berniat dan berkeinginan untuk aktif dalam kegiatan BKB demi pertumbuhan dan perkembangan anak balitanya sesuai umurnya, sedangkan 3 responden yang masih pasif dalam kegiatan BKB dikarenakan saat jadwal kegiatan $B K B$, responden tidak hadir dikarenakan bepergian. Perubahan yang signifikan pengetahuan dan keaktifan sebelum dan sesudah diberi penyuluhan ini membuktikan bahwa penyuluhan tentang BKB yang diberikan dapat diterima responden dan mempengaruhi pengetahuan dan keaktifan ibu balita dalam kegiatan BKB. 


\section{JKM (Jurnal Kebidanan Malahayati),Vol 7,No.3.Juli 2021, \\ ISSN (Print) 2476-8944 ISSN (Online) 2579-762X, Hal 562-567}

\section{SIMPULAN}

Pengetahuan sebelum diberi penyuluhan tentang BKB didapatkan hampir seluruh responden pengetahuannya cukup sebanyak 49 responden $(81,7 \%)$. Hal ini cukup baik di lihat dari segi pendidikan ibu yang rata-rata berpendidikan SMA.

Pengetahuan sesudah diberi penyuluhan tentang BKB didapatkan sebagian besar dari responden pengetahuannya cukup sebanyak 47 responden $(78,3 \%)$. Ada peningkatan responden dari yang sebelum nya ada 49 responden yang memiliki pengetahuan kurang tentang penyuluhan BKD menjadi cukup ada 47 responden. Maka hal ini sangat penting di lakukan penyuluhan tentang manfaat kegiatan BKD.

Keaktifan kegiatan BKB sebelum diberi penyuluhan tentang BKB didapatkan sebagian besar dari responden aktif sebanyak 33 responden $(55 \%)$.

Keaktifan kegiatan BKB sesudah diberi penyuluhan tentang BKB didapatkan hampir seluruh dari responden aktif sebanyak 57 responden (95\%).

Ada pengaruh penyuluhan tentang BKB (Bina Keluarga Balita) terhadap pengetahuan dan keaktifan ibu dalam kegiatan BKB di Desa Keras Kecamatan Diwek Kabupaten Jombang..

\section{SARAN}

Bagi responden / masyarakat, hendaknya hasil penelitian ini dapat dijadikan tambahan wawasan dan pengetahuan responden akan pentingnya $B K B$ sehingga dapat mendorong ibu dan keluarga untuk aktif mengikuti kegiatan Bina Keluarga Balita secara teratur..

Bagi tempat penelitian/manfaat profesi kebidanan, diharapkan hasil ini dapat dijadikan pertimbangan dalam meningkatkan pelayanan pada anak balita yang berkualitas sesuai dengan prosedur yang ada.

Bagi institusi pendidikan, diharapkan dapat menambah referensi atau literatur tentang Bina Keluarga Balita guna tumbuh kembang anak. Dan dapat di gunakan sebagai acuan pembuatan kurikulum/silabus mata kuliah asuhan kebidanan Neonatus, Bayi dan Balita

Bagi peneliti selanjutnya, diharapkan dapat dijadikan bahan pertimbangan bagi peneliti selanjutnya untuk melakukan penelitian yang lebih luas lagi dengan variabel peran kader terhadap peningkatan partisipasi ibu balita dalam BKB.

\section{DAFTAR PUSTAKA}

Arikunto, Suharsimi. 2019. Prosedur Penelitian Suatu Pendekatan Praktek. Jakarta: Rineka Cipta.

BKKBN. 2018. Panduan Pelaksanaan Kegiatan Bina Keluarga Balita (BKB) Yang
Terintegrasi Dalam Rangka Penyelenggaraan Pengembangan Anak Usia Dini Holistik Integratif. Bandung: BKKBN.

Burhanuddin. 2017. Panduan Operasional BKB. Jakarta: Kementerian Kesehatan Republik Indonesia.

Dinkes Jatim. 2018. Sosialisasi Taman Posyandu. Tersedia dari www.dinkes.jatimprov.go.id diakses pada tanggal 25 Maret 2016.

Effendy, OU. 2017. IImu Komunikasi Teori dan Praktek. Bandung: PT Remaja Rosdakarya.

Hidayat, A.A. 2018. Metode Penelitian Keperawatan \& Teknik Analisis Data. Jakarta: Salemba Medika

Kemenkes RI. 2011. Profil Kesehatan Indonesia tahun 2010. Jakarta: Kemenkes.

Machfoedz I, Sutrisno E.S, \& Santosa S. 2016. Pendidikan Kesehatan Bagian Dari Kesehatan Masyarakat. Yogjakarta: Penerbit Fitramaya.

Notoatmodjo, Soekidjo. 2017. Metode Penelitian Kesehatan. Jakarta: PT. Rineka Cipta. 2017. Promosi Kesehatan Dan IImu Perilaku. Jakarta: PT. Rineka Cipta.

Nursalam. 2018. Konsep dan Penerapan Metodologi Penelitian IImu Keperawatan. Jakarta: Salemba Medika

Rahmawati dkk, 2018. Hubungan Tingkat Pemahaman Pertumbuhan Balita Dengan Keaktifan Ibu Balita Ke Posyandu di Desa Ngawis, Karangmojo, Gunungkidul. Vol X Nomor 3.Jurnal Medika Respati.

Rustantia \& Elliana, Dewi. 2018. Hubungan pengetahuan ibu tentang Kartu Kembang Anak (KKA) dengan praktek sitmulasi perkembangan pada balita 1-3 tahun di Kelompok Bina Keluarga Balita (BKB) Puji Lestari RW I Kelurahan Ngijo Kecamatan Gunungpati Semarang. Semarang: Akbid Abdi Husada. Jurnal Penelitian IImiah.

Setiadi. 2018. Konsep dan Penulisan Riset Keperawatan. Yogyakarta: Graha IImu.

Setiawan, A. 2018. Metodologi Penelitian Kebidanan. Jakarta: Nuha Medika.

Soetjiningsih. 2018. Tumbuh Kembang Anak. Jakarta: EGC Penerbit Buku Kedokteran.

Sugiyono. 2018. Metode Penelitian Kuantitatif dan Kualitatif $R$ \& $D$. Bandung: Alfabeta.

Syafrudin. 2018. Kebidanan Komunitas. Jakarta: Salemba Medika.

Wahyuni,A., Sulistiyani., Ratnawati, L. 2018. Dampak Program Bina Keluarga Balita (BKB) Terhadap Tumbuh Kembang Anak Balita 6-24 Bulan. Jember: Universitas Jember. e-Jurnal Pustaka Kesehatan, vol. 2 (no. 1). 